\title{
Physicochemical and Biological Properties of Mycobacteriocin M12 Produced by Mycobacterium smegmatis ATCC 25855
}

\author{
By KENJI TAKEYA, MUNEAKI SHIMAMOTO AND \\ YASUO MIZUGUCHI \\ Department of Microbiology, Kyushu University, Faculty of Medicine, \\ Higashi-ku, Fukuoka City 812, Japan
}

(Received 29 March 1978; revised 28 June 1978)

\begin{abstract}
A mycobacteriocin (M12) produced by Mycobacterium smegmatis ATCC 25855 was partially purified by ammonium sulphate precipitation followed by DEAE-cellulose chromatography and Sephadex G100 chromatography. Production of M12 was maximal when bacteria were harvested after $3 \mathrm{~d}$ cultivation in liquid medium and disrupted by sonication. The molecular weight of M12, estimated by Sephadex G100 chromatography, was about 85000 . M12 was sensitive to proteolytic enzymes but resistant to DNAase and RNAase, and was relatively stable to heat treatment, sonication, ultraviolet irradiation and $\mathrm{pH}$ over the range 4 to 8 . When sensitive bacteria were exposed to the mycobacteriocin, the number of viable cells began to decrease after about $6 \mathrm{~h}$ incubation. The killing curve of M12 thus appeared to be a multiple-hit curve. Electron microscopic observation revealed that the mycobacteriocin induced morphological changes in the cells: these were partial loss of ribosomes, enlargement of lipoidal inclusion bodies and thickening of the cell envelope. The activity spectrum of M12 was restricted to the genus Mycobacterium.
\end{abstract}

\section{INTRODUCTION}

The presence of bacteriocins of mycobacteria was suggested by Adámek et al. (1968), and independently, by Imaeda \& Rieber (1968). Later, we confirmed that when appropriate indicator strains were used for the detection of bacteriocin or bacteriocin-like substances, many strains belonging to the genus Mycobacterium produced these substances; hence, classification and typing of mycobacteria were possible by their activity spectra (Takeya \& Tokiwa, 1972; Takeya \& Tokiwa, 1974).

Very little is known of the characteristics of the mycobacteriocins. We started, therefore, to investigate the nature and function of a mycobacteriocin. This paper describes some physicochemical and biological properties of mycobacteriocin M12 which is produced by Mycobacterium smegmatis ATCC 25855.

\section{METHODS}

Bacterial strains. Mycobacterium smegmatis ATCC 25855, $M$. vaccae ATCC 25952, $M$. aurum strains ATCC 25790, ATCC 25792, ATCC 25794, ATCC 25800 and $M$. fortuitum ATCC 1701 were tested for the production of mycobacteriocins. Mycobacterium diernhoferi ATCC 19340 was used as an indicator strain.

For measurement of the activity spectrum of mycobacteriocin M12, the strains listed in Table 4 were used.

Media. Heart Infusion Broth (HIB; Eiken, Tokyo, Japan) supplemented with $0 \cdot 1 \%(\mathrm{v} / \mathrm{v})$ Tween 80 and $4 \%(\mathrm{v} / \mathrm{v})$ glycerol was used as a liquid medium. To solidify the medium, 1.5 or $0.6 \%(\mathrm{w} / \mathrm{v})$ agar was added (HIA or soft agar, respectively). Ogawa's egg medium was also used as a solid medium.

Assay of bacteriocin activity. The indicator strain was subcultured on Ogawa's egg medium for $48 \mathrm{~h}$ at $37^{\circ} \mathrm{C}$. A suspension containing $1 \times 10^{8}$ bacteria $\mathrm{ml}^{-1}$ was prepared using the cells from the egg medium. A portion of this suspension $(0.5 \mathrm{ml})$ was mixed with soft agar $(5 \mathrm{ml})$ and poured on to an HIA plate. Drops of 
twofold serial dilutions of a bacteriocin suspension, sterilized by either ultraviolet (u.v.) irradiation or chloroform treatment, were spotted on to the lawn of the indicator strain. The reciprocal of the maximum dilution which produced a growth inhibition zone on the indicator strain was taken as the concentration of bacteriocin in arbitrary units (U).

Purification procedure. An exponential phase culture of $M$. smegmatis $(40 \mathrm{ml})$ was inoculated into $81 \mathrm{HIB}$ and incubated at $37^{\circ} \mathrm{C}$ for $72 \mathrm{~h}$ in a jar fermenter (Microferm; New Brunswick Scientific Co.). After incubation, bacteria were harvested by centrifugation and washed three times in Tris/ $\mathrm{NaCl} / \mathrm{MgCl}_{2}$ buffer (Tris buffer; $10 \mathrm{~mm}$-Tris adjusted to pH 7.5 with $\mathrm{HCl}, 100 \mathrm{~mm}-\mathrm{NaCl}$ and $10 \mathrm{~mm}-\mathrm{MgCl}_{2}$ ). About $20 \mathrm{~g}$ wet wt bacteria were obtained from $81 \mathrm{HIB}$. Bacteria ( $50 \mathrm{~g}$ wet wt) were suspended in $300 \mathrm{ml}$ of the same buffer and disrupted ultrasonically (Branson Sonifier Cell Disruptor 200, Branson Sonic Power Co., Danbury, Conn., U.S.A.). Cell debris was removed by centrifuging twice (13000 $\mathrm{g}$ for $20 \mathrm{~min}$ and $80000 \mathrm{~g}$ for 240 $\min$ ), and the supernatant fluid was used as the starting material for purification.

Solid ammonium sulphate was added slowly to the supernatant fluid until the solution was $40 \%$ saturated. After $2 \mathrm{~h}$ at $4{ }^{\circ} \mathrm{C}$, the precipitate was collected by centrifuging at $7000 \mathrm{~g}$ for $30 \mathrm{~min}$ and discarded. Ammonium sulphate was added to the supernatant until the solution was $60 \%$ saturated. After $2 \mathrm{~h}$ at $4{ }^{\circ} \mathrm{C}$, the precipitate was collected by centrifugation, re-dissolved in $16 \mathrm{ml}$ Tris buffer and dialysed against the same buffer for $24 \mathrm{~h}$.

A portion $(10 \mathrm{ml})$ of the ammonium sulphate fraction was applied to a DEAE-cellulose column $(1.5 \times 25$ $\mathrm{cm}$ ) pre-equilibrated with Tris buffer. Fractions of $5 \mathrm{ml}$ were collected; after elution of 40 fractions, the concentration of $\mathrm{NaCl}$ was raised to $0.7 \mathrm{M}$ with a linear gradient over 81 fractions. Fractions 48 to 57 were pooled and concentrated to $2 \mathrm{ml}$ using an ultrafiltration membrane (Amicon UM10). After centrifugation at $13000 \mathrm{~g}$ for $20 \mathrm{~min}, 1.5 \mathrm{ml}$ of the fraction was applied to a Sephadex G100 column $(1.5 \times 80 \mathrm{~cm})$ equilibrated with Tris buffer. The void volume of the column was $52 \mathrm{ml}$ and the flow rate was $3 \mathrm{ml} \mathrm{h}^{-1}$. Fractions of $1 \mathrm{ml}$ were collected at $4{ }^{\circ} \mathrm{C}$, and their absorbances at $280 \mathrm{~nm}$ and mycobacteriocin activities were assayed.

Molecular weight estimation. The molecular weight of M12 was estimated by Sephadex G100 column chromatography. The elution position of M12 in relation to other proteins of known molecular weight (Combitek calibration protein kit size 1 ; Boehringer-Mannheim) was determined.

Physicochemical properties. The heat stability of the ammonium sulphate precipitated fraction of M12 was tested by heating at $40,50,56,60,70,80$ and $100^{\circ} \mathrm{C}$ for $30 \mathrm{~min}$. Residual activities were assayed by the method described above.

The ammonium sulphate fraction of $\mathrm{M} 12$ was treated for $30 \mathrm{~min}$ at $37^{\circ} \mathrm{C}$ with the following enzymes (each at $200 \mu \mathrm{g} \mathrm{ml}^{-1}$ ): trypsin (Difco), pronase (Kaken Co., Tokyo, Japan), $\alpha$-chymotrypsin (Sigma), deoxyribonuclease I (DNAase; Sigma), ribonuclease (RNAase; Sigma). After incubation, residual activities were assayed. In the case of trypsin, trypsin inhibitor (Sigma) was added at the end of the incubation period.

The ammonium sulphate fraction of M12 in Tris buffer was mixed with equal volumes of either 0.01 M-acetate buffer (pH 4.0 and 5.0), 0.01 M-phosphate buffer (pH 6.0) or $0.01 \mathrm{M}$-Tris buffer (pH 7.0 and 8.0). Preparations were dialysed against the same buffers for $24 \mathrm{~h}$ and then assayed.

M12 was also subjected to u.v. irradiation $\left(1 \times 10^{-2} \mathrm{~J} \mathrm{~mm}^{-2}\right.$; Toshiba germicidal lamp $25 \mathrm{~W}$; Toshiba Electric Co., Tokyo, Japan), ultrasonic oscillation (200 W, $20 \mathrm{~min}$; Kubota insonator 200M; Kubota Seisakusho, Tokyo, Japan), and freezing and thawing (20 times).

Assay of protein. Protein was assayed by the method of Lowry et al. (1951).

Kinetics of killing. A suspension of the indicator strain containing about $10^{7}$ bacteria $\mathrm{ml}^{-1}$ was prepared after growth on Ogawa's egg medium or in HIB. To $1.6 \mathrm{ml}$ of the suspension, $0.4 \mathrm{ml} \mathrm{M12}\left(256 \mathrm{U} \mathrm{ml}^{-1}\right)$ was added and the mixture was incubated at $37^{\circ} \mathrm{C}$. At intervals, samples were withdrawn, diluted appropriately, and plated. Colonies were counted after about 1 week incubation at $37^{\circ} \mathrm{C}$.

Electron microscopy. Mycobacterium diernhoferi $\left(10^{8}\right.$ bacteria $\left.\mathrm{ml}^{-1}\right)$ exposed to $\mathrm{M} 12$ (final concentration $\left.56 \mathrm{U} \mathrm{ml}^{-1}\right)$ for 24 or $48 \mathrm{~h}$ were prefixed in $\mathrm{HIB}$ by adding $\mathrm{OsO}_{4}$ to a final concentration of $0 \cdot 1 \%(\mathrm{w} / \mathrm{v})$ and keeping the suspension at room temperature for about $20 \mathrm{~min}$. They were postfixed with $1 \%(\mathrm{w} / \mathrm{v})$ $\mathrm{OsO}_{4}$ and processed further according to the method of Ryter et al. (1958). Observations were made using a JEM 100 C electron microscope.

Assay of active spectrum. Mycobacterial test strains were subcultured on Ogawa's medium for $2 \mathrm{~d}$, and then suspensions of these bacteria were plated on HIA with $5 \mathrm{ml}$ soft agar. A drop of M12 suspension containing $128 \mathrm{U} \mathrm{ml}^{-1}$ was then spotted and the results were scored after 2 to $4 \mathrm{~d}$ incubation at $37^{\circ} \mathrm{C}$. Strains other than mycobacteria were subcultured on HIA without Tween 80 or glycerol and the same method was used to determine the susceptibility of these strains. 
Table 1. Adsorption of mycobacteriocin M12 to M. diernhoferi ATCC 19340 grown on different media

Suspensions containing $1 \times 10^{9}$ bacteria $\mathrm{ml}^{-1}$ were mixed with M12 preparation (final concentration $32 \mathrm{U} \mathrm{ml}^{-1}$ ). After 2 or $6 \mathrm{~h}$ incubation at $37^{\circ} \mathrm{C}$, bacteria were removed by centrifugation and the activities in the supernatant were assayed.

\begin{tabular}{|c|c|c|c|c|}
\hline \multirow[b]{2}{*}{$\begin{array}{l}\text { Bacteria obtained } \\
\text { from: }\end{array}$} & \multicolumn{2}{|c|}{$\begin{array}{c}\text { Unadsorbed } \\
\text { mycobacteriocin } \\
\left(\mathrm{U} \mathrm{ml}^{-1}\right)\end{array}$} & \multicolumn{2}{|c|}{$\begin{array}{c}\text { Adsorption } \\
(\%)\end{array}$} \\
\hline & $2 \mathrm{~h}$ & $\widetilde{6 h}$ & $2 \mathrm{~h}$ & $\overrightarrow{6 h}$ \\
\hline $\begin{array}{l}\text { Ogawa's slant } \\
\text { Heart Infusion Broth }\end{array}$ & $\begin{array}{r}4 \\
16\end{array}$ & $\begin{array}{l}2 \\
8\end{array}$ & $\begin{array}{l}87 \cdot 5 \\
50\end{array}$ & $\begin{array}{l}93 \cdot 7 \\
75\end{array}$ \\
\hline
\end{tabular}

Table 2. Production of mycobacteriocins active against $M$. diernhoferi ATCC 19340 from various mycobacterial strains

Bacteria ( $5 \mathrm{~g}$ wet wt) were suspended in $20 \mathrm{ml}$ Tris buffer and disrupted ultrasonically. Activity in the supernatant was assayed after removing cell debris by centrifugation.

$$
\begin{array}{ll}
\text { Activity } \\
\text { Strain } & \left(\mathrm{U} \mathrm{ml}^{-1}\right)
\end{array}
$$

M. vaccae ATCC 25952

M. aurum ATCC 25790

M. aurum ATCC 25792

M. aurum ATCC 25794

$M$. aurum ATCC 25800

M. smegmatis ATCC 25855

M. fortuitum ATCC 1701

Activity
(U ml $^{-1}$ )
8
8
8
8
8
32
16

\section{RESULTS}

\section{Sensitivity of indicator strain}

The sensitivity of $M$. diernhoferi to a suspension of M12 was greatly influenced by the physiological condition of the bacteria. A suspension of M12 apparently contained $256 \mathrm{U}$ when tested against cells cultured on solid media (Ogawa's egg or HIA) for 48 h, but $64 \mathrm{U}$ when tested against cells grown overnight in liquid medium (exponential phase culture). A suspension containing $10^{8}$ bacteria $\mathrm{ml}^{-1}$ obtained from Ogawa's egg medium subcultured for $48 \mathrm{~h}$ was employed routinely.

The variations in sensitivity of the indicator strain might be due to differences in adsorption of M12 on to the cell surface. To test this possibility, adsorption experiments were carried out. Suspensions $\left(10^{9}\right.$ bacteria $\left.\mathrm{ml}^{-1}\right)$ prepared from each of the different media were mixed with M12 preparation (final concentration $32 \mathrm{U} \mathrm{ml}^{-1}$ ), and the mixtures were incubated for $6 \mathrm{~h}$ at $37^{\circ} \mathrm{C}$ with gentle shaking. At 2 and $6 \mathrm{~h}$, samples were withdrawn, centrifuged to remove the cells, and the residual activities in the supernatant were assayed using bacteria from Ogawa's medium. Adsorption of M12 to the bacteria cultured on Ogawa's slant for $48 \mathrm{~h}$ was faster than to those in exponential phase obtained from liquid HIB medium (Table 1).

\section{Production of mycobacteriocins}

Seven strains of rapidly growing mycobacteria were tested for their ability to produce mycobacteriocins active against $M$. diernhoferi. None of them released bacteriocins into the medium even after 4 to $5 \mathrm{~d}$ incubation in HIB. Attempts to induce release of bacteriocin by u.v.-irradiation or mitomycin $C$ treatment were unsuccessful. It was necessary to disrupt the bacteria by sonication to release mycobacteriocins. From $5 \mathrm{~g}$ (wet wt) bacteria suspended in $20 \mathrm{ml}$ Tris buffer, activities of 8 to $32 \mathrm{U} \mathrm{ml}^{-1}$ were obtained (Table 2). The activity was highest in $M$. smegmatis. 
Table 3. Purification of mycobacteriocin M12

\begin{tabular}{|c|c|c|c|c|c|}
\hline Material & $\begin{array}{l}\text { Activity } \\
\left(\mathrm{U} \mathrm{ml}^{-1}\right)\end{array}$ & $\begin{array}{l}\text { Total } \\
\text { activity } \\
\text { (U) }\end{array}$ & $\begin{array}{c}\text { Protein } \\
\left(\mathrm{mg} \mathrm{ml}^{-1}\right)\end{array}$ & $\begin{array}{l}\text { Specific } \\
\text { activity } \\
\left(U \mathrm{mg}^{-1}\right)\end{array}$ & $\begin{array}{c}\text { Recovery } \\
(\%)\end{array}$ \\
\hline $\begin{array}{l}\text { Ultracentrifugation } \\
\text { supernatant } \\
\text { Ammonium sulphate }\end{array}$ & 16 & 3840 & $11 \cdot 0$ & $1 \cdot 4$ & 100 \\
\hline fraction & 128 & 2048 & $15 \cdot 4$ & 8 & 53 \\
\hline DEAE-cellulose & 256 & 512 & $6 \cdot 2$ & 41 & 13 \\
\hline Sephadex G100 & 64 & 96 & 0.52 & 123 & 3 \\
\hline
\end{tabular}

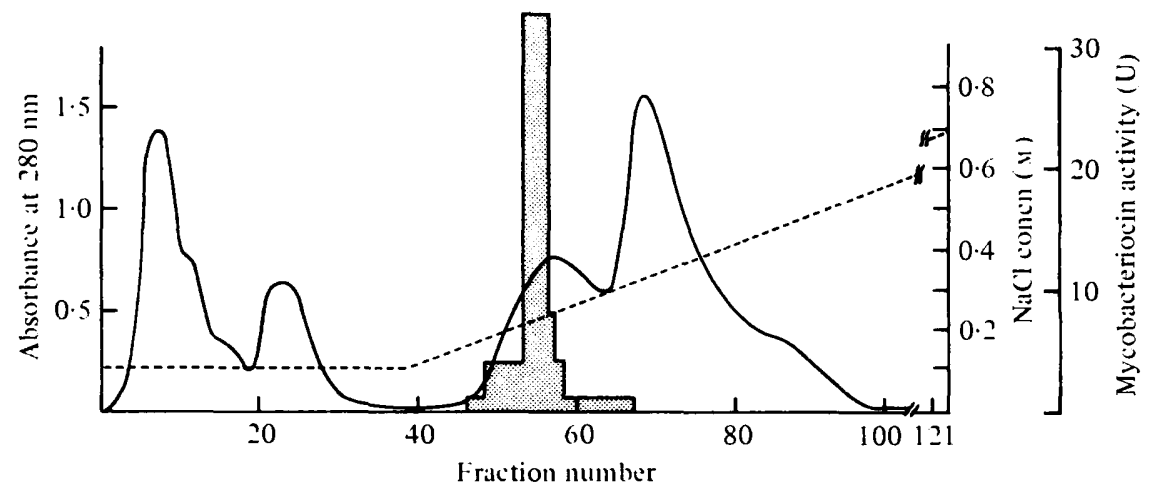

Fig. 1. Elution of mycobacteriocin M12 from DEAE-cellulose. M12 ammonium sulphate fraction $(10 \mathrm{ml})$ was applied to a DEAE-cellulose column. Fractions of $5 \mathrm{ml}$ were collected. After elution of 40 fractions, the concentration of $\mathrm{NaCl}$ was raised from 0.1 to $0.7 \mathrm{M}$ over 81 fractions with a linear gradient. - - Absorbance at $280 \mathrm{~nm}$; ---, $\mathrm{NaCl}$ concentration; dotted histogram, activity of $\mathrm{M} 12$.

\section{Partial purification of $M 12$}

The partial purification of M12, described in Methods, is summarized in Table 3. M12 activity was eluted from DEAE-cellulose as a single component at about $0.25 \mathrm{M}-\mathrm{NaCl}$ (Fig. 1). When the combined active fractions were applied to a Sephadex G100 column, the activity was eluted as a single component (Fig. 2). Only $3 \%$ of the initial activity could be recovered after the Sephadex G100 chromatography. Purification was calculated to be 88fold, but was not complete since polyacrylamide gel electrophoresis showed at least four to five different components. The elution position of M12 in relation to cytochrome $c$, chymotrypsin, hen egg albumin, bovine serum albumin, aldolase and catalase showed that the molecular weight of M12 was about 85000 .

\section{Physicochemical properties of $M 12$}

M12 (ammonium sulphate fraction) was sensitive to treatment with trypsin, $\alpha$-chymotrypsin and pronase but resistant to DNAase and RNAase.

No decrease in activity was observed after 30 min incubation at temperatures up to $56^{\circ} \mathrm{C}$, but after $30 \mathrm{~min}$ at $60{ }^{\circ} \mathrm{C}$, about $75 \%$ of the activity was lost. Surprisingly, slight activity was still detectable in the undiluted suspension after $30 \mathrm{~min}$ heating at $100^{\circ} \mathrm{C}$.

M12 was stable to u.v. irradiation, freezing and thawing, ultrasonic oscillation and changes in $\mathrm{pH}$ from 4 to 8 .

\section{Killing curve}

When $M$. diernhoferi grown on Ogawa's medium for $48 \mathrm{~h}$ was used for the killing experiments, the number of viable cells did not decrease until after $6 \mathrm{~h}$ incubation. The proportion of viable cells then decreased gradually to about $8 \%$ at $24 \mathrm{~h}$ and $0.03 \%$ after $48 \mathrm{~h}$ (Fig. $3 a$ ). 


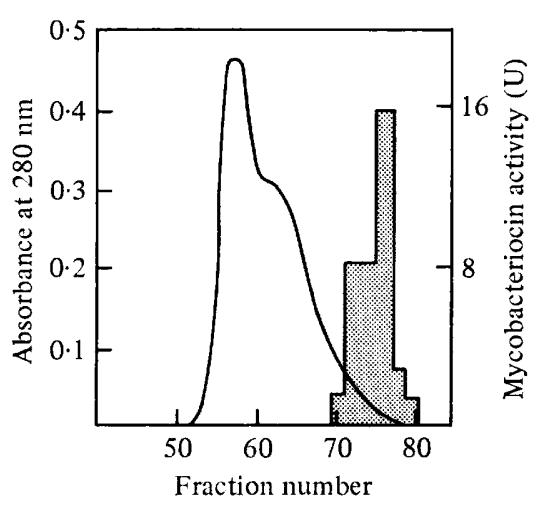

Fig. 2. Partial purification of mycobacteriocin M12 by chromatography on Sephadex G100. The concentrated preparation of M12 from DEAE-cellulose chromatography was applied to a column of Sephadex G100. The void volume, determined from the elution volume of Blue dextran, was 52 $\mathrm{ml}$. - Absorbance at $280 \mathrm{~nm}$; dotted histogram, activity of M12.
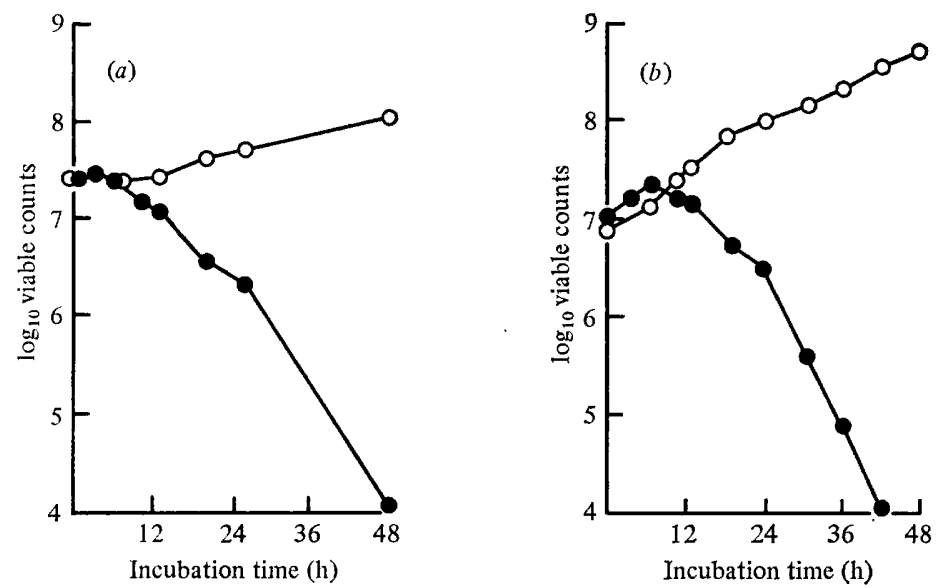

Fig. 3. Mycobacteriocin sensitivity of $M$. diernhoferi grown on solid medium $(a)$ or in liquid medium $(b)$. Suspensions of $M$. diernhoferi were mixed with $52 \mathrm{U}$ of mycobacteriocin. Samples were removed at intervals and assayed for viable colony count: $O$, without mycobacteriocin; , with mycobacteriocin.

The results indicated that killing of indicator bacteria by M12 was very slow. The curve had a shoulder, suggesting a multiple-hit process. The control culture (without M12) had a long lag time and the number of bacteria doubled after 18 to $20 \mathrm{~h}$.

Killing of indicator strain by M12 was much slower when exponential phase bacteria grown in liquid medium were employed. The number of viable cells increased during the first $6 \mathrm{~h}$ even when M12 was present in the mixture (Fig. $3 b$ ). After that the number of viable cells decreased rather rapidly; at $24 \mathrm{~h}$, about $31 \%$ of the initial cells were viable and at $48 \mathrm{~h}$, less than $0.1 \%$. Since most of the cells in the exponential phase (liquid) culture were growing, it seems unlikely that adsorption or killing requires growing cells. The generation time of $M$. diernhoferi in the untreated exponential culture was between 5 and $6 \mathrm{~h}$.

\section{Morphological changes in $M$. diernhoferi after exposure to $M 12$}

A section of an unexposed control cell of $M$. diernhoferi is shown in Fig. 4 (a); nucleoid, ribosomes and vacuole-like lipoidal inclusion bodies (Barksdale \& Kim, 1977) can be seen in the cells. Morphological changes were induced by M12. After 24 h (Fig. 4b), when about 

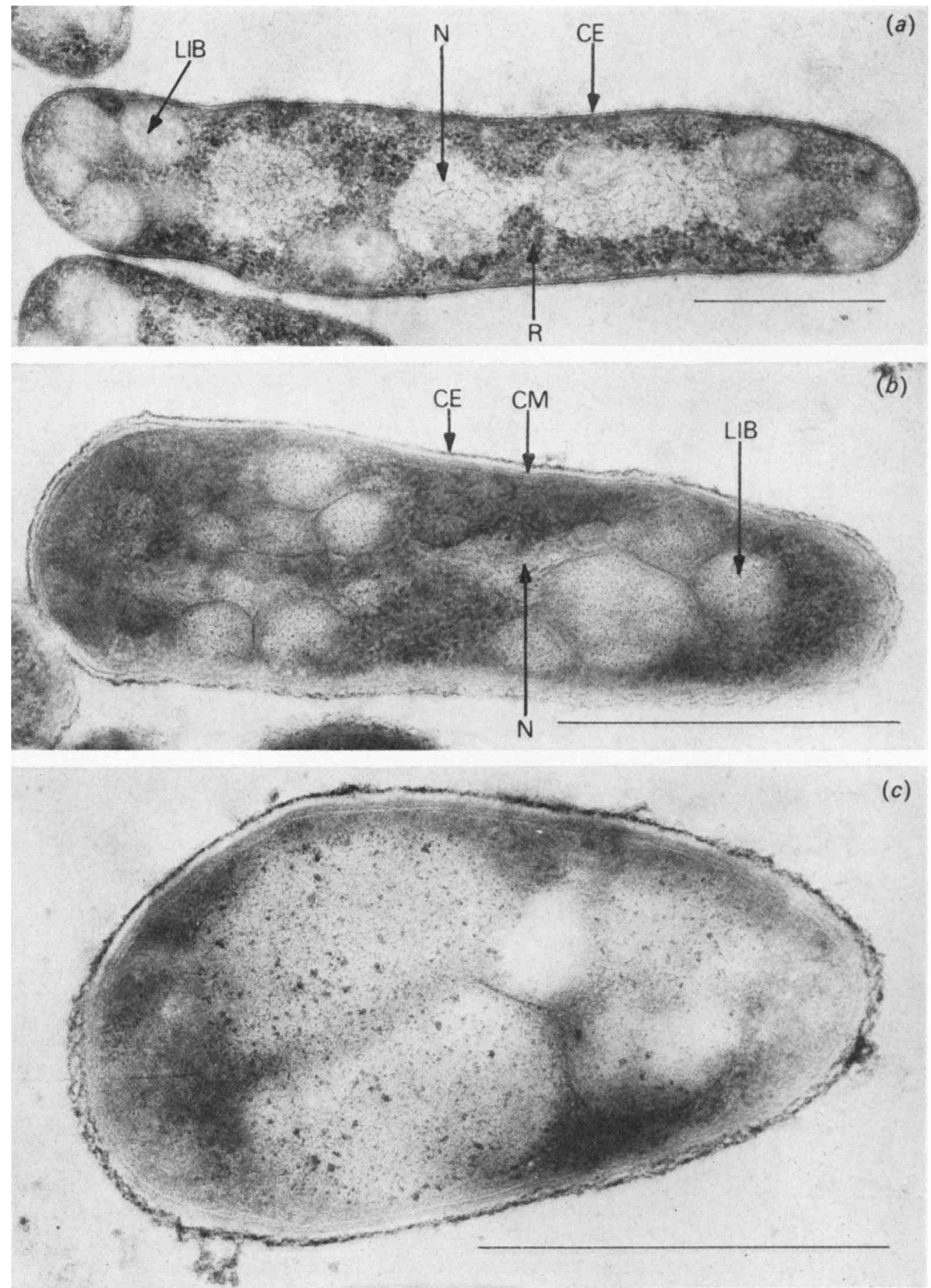

Fig. 4. Thin sections of $M$. diernhoferi, before exposure to mycobacteriocin $M 12(a)$ and after exposure to $\mathrm{M} 12$ for $24 \mathrm{~h}(b)$ or $40 \mathrm{~h}(c)$. Bar markers represent $0.5 \mu \mathrm{m}$. CE, Cell envelope; CM, cytoplasmic membrane; $N$, nucleoid; $R$, ribosomes; LIB, lipoidal inclusion body. 

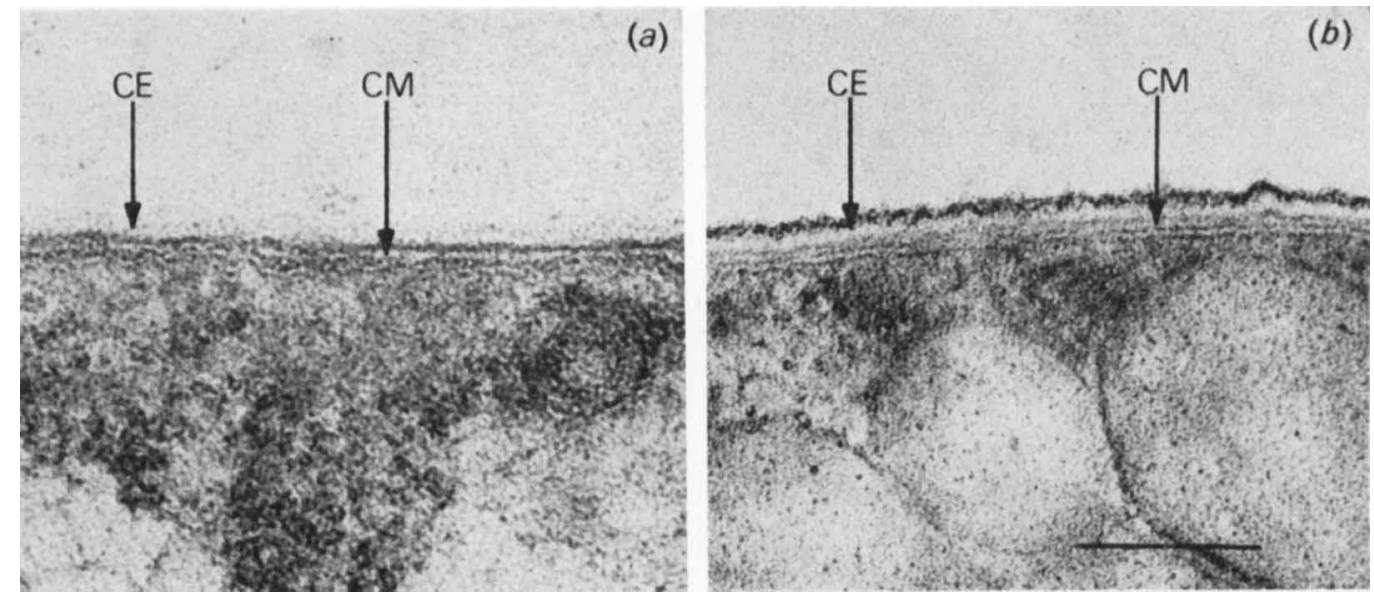

Fig. 5. Cell envelopes of $M$. diernhoferi before $(a)$ and after $(b)$ exposure to mycobacteriocin M12. Bar marker represents $0 \cdot 1 \mu \mathrm{m}$. CE, Cell envelope; CM, cytoplasmic membrane.

Table 4. Activity spectrum of mycobacteriocin $M 12$

One drop of M12 suspension containing $128 \mathrm{U} \mathrm{ml}^{-1}$ was spotted on to the lawn of test strain.

Strain tested

Mycobacterium chelonei ATCC 19977

$M$. aurum ATCC 25790

M. chitae ATCC 19627

M. flavescens ATCC 14474

M. fortuitum ATCC 19542

$M$. parafortuitum ATCC 19686

M. phlei ATCC 11758

M. smegmatis ATCC 14468

$M$. thermoresistibile ATCC 19527

M. vaccae ATCC 15483

Nocardia asteroides

Corynebacterium diphtheriae

Listeria monocytogenes

Bacillus subtilis

Klebsiella pneumoniae

Pseudomonas aeruginosa

Staphylococcus aureus
Sensitivity

+
+
+
+
+
+
+
-
+
+
-
-
-
-
-
-
-

+ , Inhibition of growth; -, no growth inhibition.

$10 \%$ of the cells were still viable, there was partial loss of ribosomes and thickening of the cell envelope. After $40 \mathrm{~h}$ (Fig. $4 c$ ), the changes were much more striking; there was loss of ribosomes and enlargement of lipoidal inclusion bodies but cell lysis was not observed.

The appearance of the normal envelope (Fig. 5a) was different from that after $40 \mathrm{~h}$ treatment with M12 (Fig. $5 b$ ). The increased thickness brought about by M12 treatment is clearly visible.

\section{Spectrum of activity}

All the rapidly growing strains of mycobacteria used in this experiment, except $M$. smegmatis, were sensitive to M12 (Table 4). Bacteria other than mycobacteria were resistant.

\section{DISCUSSION}

The sensitivity of $M$. diernhoferi to mycobacteriocin M12 was affected by the physiological condition of the cells. Such differences in sensitivity appear to be a more general 
phenomenon in the titration of bacteriocins; the titre of several types of bacteriocin must be determined under carefully standardized conditions (Tagg et al., 1976). Exponentially growing organisms are usually the most sensitive to bacteriocins and are normally used in assays. However, exponential phase cultures of $M$. diernhoferi (obtained from liquid medium) were relatively insensitive to $\mathrm{M} 12$. This might be due to a difference in adsorption of M12 on to the bacterial surface, since the decrease in bacteriocin titre after mixing was less than that obtained using bacteria grown on Ogawa's solid medium. Presumably, the latter have more exposed receptor sites than those from liquid medium.

Since the yield from $M$. smegmatis was very poor, we tried several culture media to increase the production of M12. However, none of them appeared to be effective (unpublished data), and we failed to demonstrate M12 activity in culture filtrates, even after induction. Production of bacteriocins by many Gram-positive bacteria is poor and is affected by culture conditions (Tagg et al., 1976). Mycobacteriocin M12 is thus similar to bacteriocins produced by Gram-positive bacteria. Like staphylococcin 414 (Gagliano \& Hinsdill, 1970), M12 was released from $M$. smegmatis by mechanical disruption of the cells.

Attempts to purify M12 were not satisfactory because of the low initial activity and extensive loss of activity during the purification procedure, a common problem in purifying bacteriocins of Gram-positive bacteria (Tagg et al., 1976). Stability of bacteriocins produced by Clostridium botulinum, $C$. perfringens and group A streptococci decreases dramatically with increased purification (Ellison \& Kautler, 1970; Mahony, 1974; Tagg et al., 1973a).

Bacteriocin M12 is small, with a molecular weight of about 85000 . Its active moiety seems to be a protein, since it is sensitive to proteolytic enzymes. A mycobacteriocin produced by $M$. tuberculosis was also sensitive to proteolytic enzymes (Takeya \& Tokiwa, 1974).

The very slow progress of killing suggested either that adsorption of M12 on to the cell surface was very slow or that there might be a reversible period during which binding does not necessarily result in death. Adsorption experiments (Table 1) indicated the latter possibility, since $87.5 \%$ of the bacteriocin was adsorbed to the cell surface after $2 \mathrm{~h}$ incubation. However, cell concentrations used in the adsorption experiments were at least 50 times higher than those in the killing experiments, so the amount of adsorbed bacteriocin in the killing experiments must be less than those observed in the adsorption experiments.

The killing curve of M12 resembled a multiple-hit curve, suggesting that cumulative action by more than one bacteriocin molecule may be necessary to kill the cells. Most bacteriocins kill sensitive cells by single-hit kinetics. One possible explanation of multiplehit killing is that the cells used in the experiments were clumped. However, this seems unlikely, because 70 to $90 \%$ of the population were seen by microscopy to be single cells, whilst by extrapolation from Fig. 3(b), the number of hits is estimated to be between 5 and 10. Whatever the mechanism of the multiple-hit killing, this character of M12 may contribute to the slow progress of killing.

There have been relatively few reports on the morphological changes induced by bacteriocins. Ohnishi (1969) observed degradation of the nucleoid of Pseudomonas aeruginosa by pyocin 28. After exposure of group A streptococcus to staphylococcin C55, condensation of nuclear material, partial loss of ribosomes, modification of mesosomes and eventual dissolution of cell contents occurred (Clawson \& Dajani, 1970). Similar changes were observed with streptococcin A-FF22 (Tagg et al., 1973b) and boticin E-S5 (Ellison et al., 1971). Changes induced by mycobacteriocin M12 seem to be similar to those induced by streptococcin C55, except for the changes in cell envelope. M12 did not lyse cells; indeed it induced a thickening of the cell envelope. It is not known what metabolic disorder induced such morphological changes. Attempts to detect the specific biochemical lesions within affected cells are in progress.

We thank Mr A. Takaide for his skilful help in electron microscopic observation. 


\section{REFERENCES}

AdámeK, L., Trnka, L., Mišoň, P. \& Gutová, M. (1968). Hemmstoffe von Bakteriocin Typus bei schnell wachsenden saprophytischen Stämmen der Mykobakterien. Beiträge zur Klinik der Tuberkulose und zur spezifischen Tuberkuloseforschung 138, 51-55.

BARKSDALE, L. \& KIM, K. S. (1977). Mycobacterium. Bacteriological Reviews 41, 217-372.

Clawson, C. C. \& Dajani, A. S. (1970). Effect of bactericidal substance from Staphylococcus aureus on group A streptococci. Il. Structural alterations. Infection and Immunity 1, 491-498.

Ellison, J. S. \& Kautler, J. A. (1970). Purification and some properties of two boticins. Journal of Bacteriology 104, 19-26.

Ellison, J. S., Mattern, C. F. T. \& Daniel, W. A. (1971). Structural changes in Clostridium botulinum type $\mathrm{E}$ after treatment with boticin $\mathrm{S} 5_{1}$. Journal of Bacteriology 108, 526-534.

Gagliano, V. J. \& Hinsdill, R. D. (1970). Characterization of a Staphylococcus aureus bacteriocin. Journal of Bacteriology 104, 117-125.

IMAEDA, T. \& RIEBER, M. (1968). Mitomycin Cinduced phage-like particles in a mutant of Mycobacterium tuberculosis BCG. Journal of Bacteriology 96, 557-559.

Lowry, O. H., Rosebrough, N. J., FARr, A. L. \& Randall, R. J. (1951). Protein measurement with the Folin phenol reagent. Journal of Biological Chemistry 193, 265-275.

MAHONY, D. E. (1974). Bacteriocin susceptibility of
Clostridium perfingens. A provisional typing schema. Applied Microbiology 28, 172-176.

OHNISHI, K. (1969). Effect of pyocin 28 on the sensitive indicator strain. Fukuoka acta medica 60, 577-590 (in Japanese).

Ryter, A., Kellenberger, E., Birch-Andersen, A. \& MaAloe, O. (1958). Etude au microscope électronique de plasmas contenant de l'acide désoxyribonucléique. I. Les nucléoides des bactéries en croissance active. Zeitschrift für Naturforschung 13b, 597-605.

TAGG, J. R., Dajani, A. S., Wannamaker, L. W. \& GraY, E. D. (1973a). Group A streptococcal bacteriocin. Production, purification and mode of action. Journal of Experimental Medicine 138, 1168-1183.

TAGG, J. R., Pihl, E. A. \& McGiven, A. R. (1973b). Morphological changes in a susceptible strain of Streptococcus pyogenes treated with streptocin A. Journal of General Microbiology 79, 167-169.

TAGG, J. R., Dajani, A. S. \& Wannamaker, L. W. (1976). Bacteriocins of gram positive bacteria. Bacteriological Reviews 40, 722-756.

TAKEYA, K. \& Tokiwa, H. (1972). Mycobacteriocin classification of rapidly growing mycobacteria. International Journal of Systematic Bacteriology 22, 178-180.

TAKeYA, K. \& Tokiwa, H. (1974). Bacteriocin typing of Mycobacterium tuberculosis. American Review of Respiratory Disease 109, 304-305. 